\title{
ICTОРІЯ НАУКИ
}

УдК 9/904+061

ГРИЦЮТА Оксана Олександрівна

Південноукраїнський національний

Педагогічний університет ім. К. Д. Ушинського

вул. Старопортофранківська 26, Одеса, 65000

e-mail: grytsyuta2@gmail.com

https://orcid.org/0000-0003-3694-3257

\section{НАУКОВІ ПОШУКИ ІСТОРИЧНОГО ТОВАРИСТВА НЕСТОРА-ЛІТОПИСЦЯ В ГАЛУЗІ АРХЕОЛОГІї}

Анотація. Стаття присвячена історії археологічних досліджень, що проводились Історичним товариством Нестора Літописия (ITНЛ) при Київському університеті св. Володимира. Членами Товариства були такі відомі вчені як В. Б. Антонович, С. Гамченко. В. Завітневич та інші. Відповідно до Статуту Товариства, його метою було сприяти розвитку історичної науки з усіма допоміжними науками. Одним з найважливіших напрямів наукової діяльності Товариства було проведення археологічних досліджень Значне місце серед доповідей, зроблених на засіданнях ІТНЛ, займають публікації про результати розкопок. Географічно ці дослідження охоплювали практично всю територію Півдня Російської імперії. Значні розкопки були проведені в Південній Бессарабії, Києві, Волині, Полтавській губернії та Криму. Діяльність представників Історичного товариства Нестора Літописця в II половині XIX століття ознаменувалася заходами, спрямованими на формування та розвиток археології як історичної науки на українських землях. Це знайшло відображення в активних польових заходах (розкопки, дослідження), численних звітах, представлених на засіданнях Товариства. Археологи, які входили до ІТНЛ, сприяли введенню в науку унікальних матеріальних доказів, які дозволили нам відновити погляд на минуле.

Ключові слова: Історичне товариство Нестора-літописця; польові дослідження; археологія; М. Ф. Берлінський; В. Б. Антонович

Часом початку систематичних археологічних досліджень на території Лівобережної України традиційно вважають 30-і р. XIX ст. В цей період в Російській імперії зріс інтерес до минувшини, почали створюватися аматорські та професійні об'єднання істориків. Особливо актуальними були дослідження в галузі стародавньої історії, що призвело до активного розвитку археології. В результаті накопичення і осмислення археологічних матеріалів значно поповнилася джерельна база даних для безписемного періоду нашої історії. Таким чином, з'явилася можливість розвивати такі напрямки як первісна історія, історія античності, давньослов'янський період, історія Київської Русі.

Процес пожвавлення інтересу до такого роду досліджень створив умови для початку наукових пошуків, які ставили собі за мету 
накопичення інформації та формування методології археологічних досліджень. Одним з перших вітчизняних вчених, які зацікавилися археологічними дослідженнями Києва був Максим Федорович Берлінський. Він був автором книги «Краткое описание Киева, содержащее историческую перечень сего города, а также показание достопримечательностей и древностей оного» (1820р.). У цій книзі автор локалізував історичні райони міста і конкретні пам'ятники старовини, правильно визначив Старокиївську гору як перше місце перебування засновника Києва князя Кия. Книга стала документальним фундаментом усіх наступних досліджень найдавнішої історії міста.

Для написання своєї роботи М. Ф. Берлінський, поряд з даними письмових джерел, використовував археологічні матеріали. Він фіксував знахідки на мапі, робив замальовки. Таким чином було зафіксовано цілу низку об'єктів, які до нашого часу не збереглися. М. Ф. Берлінський вперше ввів в науковий обіг археологічні джерела з давньої історії Києва, ставши родоначальником нового напряму - церковної археології [1].

Поява масових археологічних знахідок в Києві пов'язана 3 інтенсифікацією будівництва. Ініціаторами перших планомірних археологічних робіт були археолог-любитель Кіндрат Лохвицький і митрополит Євгеній Болховітінов. У 1824 р, під їх керівництвом були проведені розкопки Десятинної церкви. Ними велися роботи по дослідженню фундаментів Іринінської церкви, храмів навколо садиби Софійського собору, церкви у Йорданського струмка на Подолі. 31832 по 1838 р.p. вони розкопували залишки Золотих воріт [2, С. 15-23]. Згодом до К. Лохвицького та митрополита Євгенія, приєднались інші дослідники, почався процес формування наукового археологічного осередку.

Ще одним потужним поштовхом до розвитку української археології було відкриття в 1834 р. Київського університету св. Володимира. Університет 3 перших же років свого існування став центром по виявленню, збиранню і вивченню пам'яток старовини. Через рік при ньому був заснований "Тимчасовий комітет пошуків старожитностей", численні матеріали, зібрані Комітетом, надходили в Київський університет. Ця колекція стала підставою для відкриття при університеті археологічного музею у1837 р. В 1859 р. Була заснована Археологічна комісія (діяла до 1917 г.). Активну діяльність по фіксації археологічних пам'яток України розгорнула створена в 1843 р У Києві Тимчасова комісія для розгляду давніх актів. У 1845-1846 р.р. Співробітником цієї комісії був Т. Шевченко [3, С. 95-98].

Археологічні дослідження другої половини XIX ст. охопили майже всю територію України. Археологія стала однією з провідних навчальних дисциплін в університетах Києва, Одеси, Харкова, Львова. Почалося дослідження пам'яток епохи палеоліту, трипільської культури, курганів епохи міді, бронзи, розкопки античних міст Північного Причорномор'я. 
Таким чином, стало очевидним, що до 70-х років XIX ст. назріла необхідність інституціоналізувати цю сферу, що і привело до формування відповідних організацій, в діяльності яких в подальшому було реалізовано інтелектуальний і дослідницький потенціал. Саме цей процес і висунув Київ на лідируючі позиції серед інших центрів археології Південного Заходу Російської імперії.

Важливим етапом у розвитку археології Південно-Західного краю було створення в 1873 р Історичного товариства Нестора-літописця (ITHЛ) при Київському університеті - об'єднання професійних істориків і археологів. У різні роки в нього входили такі відомі історики як Костомаров М. І., Антонович В. Б., Володимирський-Буданов М. Ф., Котляревський О. О., Багалій Д.І. та багато інших. Його членами були ректори та професори 3 інших університетів (Московського, Петербурзького, Варшавського, Віденського, Тартуського, Харківського та ін.), а також викладачі гімназій. Воно підтримувало тісні наукові зв'язки з аналогічними товариствами Москви, Санкт-Петербургу та інших міст.

Питання стосовно заснування, етапів та напрямків діяльності Історичного Товариства Нестора-літописця привертали увагу спеціалістів 3 дореволюційних часів. Перші спроби узагальнити історію Товариства були зроблені вченими, які входили до його складу. Серед них слід пригадати роботу Н. П. Дашкевича [4]. Автор докладно викладає історичні обставини створення ІТНЛ та початковий етап діяльності Товариства. Кілька узагальнюючих робіт було опубліковано у радянські часи, наприклад, стаття М. П. Колесниченко «Історичне товариство Несторалітописця: основні напрями діяльності (1872-1931 р.р.)». В ній діяльність Товариства поділяється на декілька етапів, але не робиться спроби проаналізувати напрямки наукової діяльності ITHЛ [5].

Сучасні українські історики розробляли питання діяльності Історичного товариства Нестора-літописця в окремі періоди його роботи, серед іншого вивчалася наукова діяльність членів осередку. Так, у своєму дослідженні Л. Федорова розглянула пам'яткоохорнну діяльність Товариства. Вона наголосила на тому, що саме ITHЛ першим здійснило спробу скласти реєстр пам'яток Київського, Подільського та Волинського генерал-губернаторства. А в 1898 р. в часописі товариства була опублікована «Програма для збирання відомостей про старожитності» [6]. Л. Баженов звертає увагу на те, що в працях членів Товариства була широко відображена історико-краєзнавча тематика, зокрема присвячена вивченню Правобережної України [7]. Роль Товариства в джерелознавчих студіях дослідила Л. Б. Круглова. Їй вдалося з'ясувати, що одним із пріоритетних напрями напрямів діяльності ЧИОНЛ було виявлення, дослідження та публікація писемних джерел 3 історії України. В ії дослідженні було встановлено, що серед документальних публікацій переважають актові матеріали, зокрема, гетьманські універсали, укази 
польських королів та російських царів, матеріали соціально-економічного та юридичного характеру. Вони містили інформацію переважно з історії Гетьманщини, Запорізької Січі, національно-визвольних рухів та козацьких війн, відображали соціально-економічні процеси, висвітлювали церковну історію та історію української культури, характеризували діяльність окремих навчальних закладів [8].

Серед маси історичних робіт, присвячених напрямкам наукової діяльності ІТНЛ нам не вдалося знайти жодного цілісного дослідження, присвяченого вивченню наукового доробку Товариства в галузі археології. Тому метою нашого дослідження $€$ висвітлення наукової діяльності Історичного товариства Нестора-літописця в галузі археологічної науки.

Ідея створення ІТНЛ належала професору Київського університету М. О. Максимовичу. На початку 40-х років XIX ст. в Києві був організований гурток місцевих істориків. Максимович, взявши за основу Статути Московського і Одеського товариств, склав проект Статуту Київського товариства історії та старожитностей слов'яно-російських та представив клопотання про його затвердження. Місцева влада проект підтримала, однак царський уряд відхилив це прохання.

Пізніше, в 1871 р., М. А. Максимович повернувся до ідеї організації історичного товариства, проте втілити ії в життя вдалося I. П. Хрущову, доценту кафедри російської словесності Київського університету. Офіційно відкриття товариства відбулося 14 січня 1873 р., першим главою ITНЛ був М. А. Тулов. 31874 по 1877 р.р. Суспільство очолював відомий історик В. С. Іконніков, при якому Товариство зазнало серйозних організаційних змін. В. Іконников реорганізував роботу і життя Товариства, зв'язавши останнє 3 Київським університетом. У його каденцію членами ІТНЛ стали викладачі історико-філологічного факультету університету св. Володимира, членство в ІТНЛ стало престижним. Наукові засідання почали проходити на регулярній основі і стали публічними. В. Іконников доклав значних зусиль для створення бібліотеки Товариства Нестора-літописця. Величезною заслугою професора Іконннікова була організація друкованого видання ІТНЛ - «Читання в Історичному товаристві Несторалітописця». В цілому було видано 24 книги в 48 випусках (1879-1914 р.p.) [4, С. 23].

Відповідно до Статуту Товариства, його метою було сприяти розвитку історичної науки з усіма допоміжними до неї напрямками. Тому в ІТНЛ розвивалися археографія, проводилися етнографічні i антропологічні дослідження. Як вже зазначалося вище, одним 3 важливих напрямків наукової діяльності Товариства були археологічні пошуки. У «Читаннях в Історичному товаристві Нестора-літописця» опубліковано близько ста двадцяти статей на археологічну тематику. Це дослідження археологічних пам'яток, публікація результатів розкопок і підготовка карт, робота 3 
музеєфікації, і вивчення знайдених монет і скарбів, організація археологічних з'їздів.

Значне місце серед доповідей, зроблених на засіданнях ITHЛ займають публікації, присвячені результатам польових досліджень та археологічним розвідкам, або, як вони тоді називалися, - археологічним екскурсіям. Географічно ці дослідження охоплювали практично всю територію Півдня Російської імперії, відомі звіти про археологічні екскурсії археолога В.З.Завитневича в Прип'ятське Полісся, верхнє Подніпров'я розвідки в Полтавській і Київській губерніях, Криму тощо.

У 1891 році Товариством Нестора-літописця була організована археологічна екскурсія в Аккерманський повіт, під час якої відомим археологом Ф. І. Кнауером був досліджений «подвійний курган» в селі Павлівка Акерманського повіту. Насправді була виявлена група з трьох курганів, які мали незвичайну структуру. У них знаходилося близько 30 поховань різного часу. Дані матеріали зацікавили В. Б. Антоновича. Розглянувши їх, він прийшов до висновку, що кургани були насипані не одночасно, а протягом певного періоду, оскільки в них знаходилися поховання кількох епох. Нові матеріали дозволили переглянути раніше зроблені висновки і правильно інтерпретувати знахідки з курганів як «або повністю кам'яного віку, або ті, що знаходяться на межі кам'яного i бронзового століть». 3 огляду на складну стратиграфію досліджених насипів вірним було зауваження, що «скелети були розташовані поверхами», в сучасній археології такий тип поховання отримав назву «впускні поховання». Це один 3 перших наукових висновків про планіграфію горизонтів курганних насипів [9, С. 11].

Археологічні дослідження стародавнього Києва можна назвати пріоритетними в ІТНЛ. Серед звітів про результати розкопок більшу частину займали доповіді, присвячені саме цьому періоду. Так, в березні 1876 В. Б. Антонович разом з О. С. Роговичем досліджували групу печер у Кирилівського монастиря. В результаті вдалося зібрати інформацію про 45 печер, які тягнулися від Межигір'я до с. Монастирка, а також були приведені їх кількісні показники. Було з'ясовано, що печери знаходяться не відокремлено, а пов'язані між собою. Найбільш ранні археологічні свідчення, знайдені у печерах, на думку автора, відносяться до часу переходу від кам'яного до бронзового віку. Крім того, в результаті розкопок вдалося скласти план печерного містечка, де жили ченці, починаючи з IX ст.

Подальші розкопки, проведені поблизу Києва (в околиці Китаєвої пустелі) дозволили виявити стародавнє городище, М. О. Максимович припустив, що це Пересічен - центр землі уличів. На північний захід від городища були виявлені 500 курганів, віднесені до християнських часів. Деякі з археологічних знахідок були представлені під час доповіді для 
наочного ознайомлення з матеріалом і наступним оформленням у фонди університетської музею [10, 246-250].

Слід зазначити, що звіти про дослідження пам'яток давньоруської доби становили чималу частину археологічних доповідей, прочитаних на засіданні ІТНЛ, з огляду на це можна припустити, що в Товаристві сформувався центр давньоруської археології, де поряд з В. Антоновичем успішно працювали такі відомі дослідники як С. 3 . Гамченко, Н. I. Дашкевич, В. З. Завитневич і ін.

Ще одним значущим напрямком польових археологічних ITHЛ досліджень були розкопки пам'яток античної епохи в Криму. Протягом декількох польових сезонів, починаючи з 1890 р, під керівництвом відомого історика-антикознавця Ю.А. Кулаковського проводилися розкопки поблизу м. Керч. У перший сезон розкопок у гори Мітрідат йому вдалося відкрити кілька склепів з написами і розписами, серед яких унікальний християнський склеп з написаною на стіні датою 491. Стіни склепу були покриті написами, що представляють псалми і молитви, на думку автора вони відповідали обряду освячення печери, де знаходився склеп. При чому, було помічено, що спосіб побудови склепу не відрізняється від язичницьких печер того ж часу, що дало можливість припустити, що поховання належало місцевим готам, які не втратили християнство під впливом гунів. Надалі розкопки були продовжені, ïx результати мали велике значення для вивчення давньої історії Криму [11, С. 20-25]. Дослідження Ю. А. Кулаковського дозволили почати систематичні розкопки стародавнього Пантікапея, завдяки його зусиллям вдалося зберегти унікальні археологічні матеріали, які $\epsilon$ предметом пильного вивчення сучасних вчених

Члени ІТНЛ були учасниками розкопок і розвідок і в інших регіонах. Так, в 1879 р за дорученням попереднього комітету Тифліського археологічного з'їзду В. Антонович взяв участь в екскурсії по північному схилу Кавказу. Завданням даної експедиції було знайти зв'язок між древніми народами Кавказу і Росії, а також з'ясувати чи був зв'язок між матеріальною культурою Кавказу та культурами Центральної Азії і Східною Європою.

Для вирішення поставлених завдань були проведені розкопки в кобанський ущелині, в результаті яких був розкопано 17 гробниць і 72 кургану. Після вивчення результатів розкопок, Антонович виділив кілька типів гробниць: печерні могильники, могильники у вигляді кам'яних ящиків, надземні гробниці. Грунтуючись на знахідках візантійських монет автор датував пам'ятники не пізніше VII н. е. В. Антонович, також, зауважив, що довести зв'язок між культурами Кавказу та Східної Європи не вдалося [12, С. 116-118].

Діяльність представників Історичного товариства Нестора-літописця у II пол. XIX ст. відзначалася заходами, спрямованими на становлення і 
розвиток археології як історичної науки на українських землях. Це знайшло своє відображення в активній польовий діяльності (розкопки, розвідки), численних доповідях, представлених на засіданнях Товариства. Вчені-археологи, які входили до складу ІТНЛ зробили дуже багато для збереження і введення в науковий обіг унікальних матеріальних свідчень, які дозволили нам відновити картину минулого.

\section{Джерела та література}

1. Грицюта О. О. «Перший Київський Археолог» М. Ф. Берлінський. Двадиять третя всеукраїнська наукова конференція молодих істориків науки, техніки і освіти та спеціалістів, присвячена 100-річчю національної академії наук України: мат. конф., 20 квітня 2018 р., м. Київ. К., 2018, С. 39-41.

2. Ананьева Т. Десятинна церква: коло витоків досліджень. Церква Богородиці Десятинна в Киеві. До 1000-ліття освячення, К. 1996, 215 с.

3. Линёва Е.А. Предпосылки и история зарождения отечественной археологии. Vita Antiqua. 1999. №1. С. 99-106.

4. Дашкевич Н.П. Историческая записка о возникновении и деятельности Исторического Общества Нестора-летописца по январь 1898. Чтения в Историческом обществе Нестора-летописца. 1899. Кн. 13. Отд.1. С.17-98.

5. Колесник М.П. Історичне товариство Нестора-літописця: основні етапи й напрями діяльності ( 1872-1931рр. ). Украӥнський історичний журнал. 1989. № 9. С. 50-56.

6. Федорова Л. Виникнення загальноукраїнських громадських форм охорони пам'яток історії та культури (1870-ті - початок 1900-х рр.). Київська старовина. 2011. № 1. С. 65-86.

7. Баженов Л. В. Історичне краєзнавство Правобережної України XIX - на початку XX ст. : Становлення. Історіографія. Бібліографія. Хмельницький: Доля, 1995. - 255 с.

8. Круглова Л. Б. Публікація джерел з історії України на сторінках наукового часопису «Чтения в историческом обществе Нестора-летописца» (1879-1914 рр.) : автореф. дис. на здобуття наук. ступеня канд. іст. наук : 07.00.06. Київ, 2009. - 17 с.

9. Кнауэр Ф. И. Результаты археологической экскурсии в Акерманский уезд, предпринятой весной 1891 г. Чтения в историческом обществе Несторалетописца. 1892. Кн. 6. С. 10-13.

10. Антонович В.Б. Археологические находки и раскопки в Киеве и в Киевской губернии в течении 1876 года. Чтения в историческом обществе Несторалетописца. 1879. Кн. 1. С. $244-261$.

11. Кулаковский Ю. А. Археологические раскопки близ Керчи летом 1890 г. Чтения в историческом обществе Нестора-летописца. 1891. Кн. 5. С. 20-25.

12. Антонович В. Б. О результатах археологической экскурсии по северному склону Кавказа, совершенной летом 1879 г. Чтения в Историческом обществе Несторалетописца. 1880. Кн 2. С. 114-118.

Грицюта Оксана Александровна

Южноукраинский национальный

Педагогический университет им. К. Д. Ушинского

ул. Старопортофранковская 26 Одесса, 65000 


\title{
Научные изыскания исторического общества Нестора-летописца в области археологии
}

\begin{abstract}
Анотация. Статья посвящена истории археологических исследований, проводимых Историческим обществом Нестора Летописца (ИОНЛ) при Киевском университете св. Владимира. Членами Общества были такие известные ученые как В. Б. Антонович, С. Гамченко. В. Завитневич и другие. В соответствии с Уставом Общества, его целью было способствовать развитию исторической науки со всеми вспомогательными науками. Одним из важнейших направлений научной деятельности Общества было проведение археологических исследований Значительное место среди докладов, сделанных на заседаниях ИОНЛ, занимают публикации о результатах раскопок. Географически эти исследования охватывали практически всю территорию Юга Российской империи. Значительные раскопки были проведены в Южной Бессарабии, Киеве, Волыни, Полтавской губернии и Крыма. Деятельность представителей Исторического общества Нестора Летописца во II половине ХІХ века ознаменовалась мерами, направленными на формирование и развитие археологии как исторической науки на украинских землях. Это нашло отражение в активных полевых мероприятиях (раскопки, исследования), многочисленных отчетах, представленных на заседаниях Общества. Археологи, которые входили в ИОНЛ, способствовали введению в научный оборот уникальных материальных доказательств, которые позволили нам восстановить картину прошлого
\end{abstract}

Ключевые слова: Историческое общество Нестора-летописиа; полевые исследования; археология; М. Ф. Берлинский; В. Б. Антонович

\section{Hritsuta Oksana}

The South Ukrainian National

Pedagogical University. K. D. Ushinsky

Staroportofrankovskaya St., 26 Odessa, Ukraine, 65000

\section{Scientific research of the historical society of Nestor the Chronicler in the field of archeology}

Abstract. The article is devoted to the history of field archaeological research of ongoing by the Historical Society of Nestor the Chronicler at the Kiev University of St. Vladimir (HSNC). The members of the Society were such famous scientists as V. B. Antonovich, S. Gamchenko. V. Zavitnevich and others. According to the Statute of the Society, its goal was to promote the development of historical science with all its subsidiary directions. One of the most important areas of the scientific activity of the Society was archaeological research. A significant place among the reports made at the meetings of the HSNC is occupied by publications on the results of field research and archaeological exploring or, as they were then called, archaeological excursions. Geographically, these studies covered practically the entire territory of the South of the Russian Empire. Significant excavations were carried out in Southern Bessarabia, Kyiv, Volyn and Poltava province and the Crimea. Activities of representatives of the Historical Society of Nestor the Chronicler in the II half of XIX century was marked by measures aimed at the formation and development of archeology as a historical science on the Ukrainian lands. This was reflected in the active field activities (excavations, exploration), numerous reports presented at the meetings of the Society. The archeologists, why were he members of the HSNC, did a lot introduce into the science unique material evidence that allowed us to restore the view of the past.

Keywords: Historical Society of Nestor the Chronicler; field studies; archeology; M. F. Berlinsky; V. B. Antonovich 


\section{References}

1. Hrytsiuta 0. O. (2018). «Pershyi Kyivskyi Arkheoloh» M. F. Berlinskyi. [First Kyiv archeologist M. F. Berlinsky]. Dvadtsiat tretia vseukrainska naukova konferentsiia molodykh istorykiv nauky, tekhniky $i$ osvity ta spetsialistiv, prysviachena 100-richchiu natsionalnoi akademii nauk Ukrainy. Twenty-third All Ukrainian scientific conference of young historians of science, technology and education and specialists dedicated to the 100th anniversary of the National Academy of Sciences of Ukraine, (pp. 39-41). Kyiv [in Ukrainian].

2. Ananeva T. (1996) Desiatynna tserkva: kolo vytokiv doslidzhen. [The Desiatynna Church : the area of research origins.] Tserkva Bohorodytsi Desiatynna v Kyevi. Do 1000-littia osviachennia - The Desiatynna Church of Our Lady in Kiev. To the 1000th anniversary of consecration, (215 p.) Kyiv [in Ukrainian].

3. Linyova E.A (1999). Predposyilki i istoriya zarozhdeniya otechestvennoy arheologii [Background and history of the birth of domestic archeology]. Vita Antiqua, 1, 99-106 Kyiv [in Russian].

4. Dashkevich N.P. (1899) Istoricheskaya zapiska o vozniknovenii i deyatelnosti Istoricheskogo Obschestva Nestora-letopistsa po yanvar 1898 [Historical note on the origin and activities of the Historical Society of Nestor the Chronicler until January 1898]. Chteniya $v$ Istoricheskom obschestve Nestora-letopistsa - Readings in the Historical Society of Nestor the Chronicler, 13, 17-98 [in Russian].

5. Kolesnik M.P. (1989) Istorichne tovaristvo Nestora-litopistsya: osnovni etapi y napryami diyalnosti ( 1872-1931 rr. ) [Historical Society of Nestor-chronicler: the main stages and directions of activity (1872-1931)]. Ukrayinskiy Istorichniy zhurnal - Ukrainian Historical Magazine, 9. pp. 50-56. Kyiv [in Ukrainian].

6. Fedorova L. ( 2011) Viniknennya zagalnoukrayinskih gromadskih form ohoroni pam'yatok Istoriyi ta kulturi (1870-ti- pochatok 1900-h rr.) [The emergence of all-Ukrainian public forms of protection of historical and cultural sites (1870s - early 1900's).]. Kiyivska starovina, 1. pp. 65-86. Kyiv [in Ukrainian].

7. Bazhenov L. V. (1995) Istorichne krayznavstvo Pravoberezhnoнi Ukraнini XIX - na pochatku XX st.: Stanovlennya. Istoriografiya. Bibliografya [Historical regional studies of Right-bank Ukraine of the XIXth - beginning of the 20th century: becoming. Historiography. Bibliography.]. Hmelnitskiy : Dolya.

8. Kruglova L. B. (2009) Pubilkatsiya dzherel z Istoriyi Ukrayini na storinkah naukovogo chasopisu «Chteniya v istoricheskom obschestve Nestora-letopistsa» (1879-1914 rr.) [Publication of sources on the history of Ukraine on the pages of the scientific journal "Readings in the Historical Society of the Nestor Chronicler" (1879-1914).]. Extended abstract of candidate's thesis. Kyiv [in Ukrainian].

9. Knauer F. I. ( 1892) Rezultatyi arheologicheskoy ekskursii v Akermanskiy uezd, predprinyatoy vesnoy $1891 \mathrm{~g}$. [The results of an archaeological excursion to the Akerman County, undertaken in the spring of 1891 ] Chteniya $v$ istoricheskom obschestve Nestoraletopistsa - Readings in the Historical Society of Nestor the Chronicler, 6, 10-13. [in Russian].

10. Antonovich V.B. (1879) Arheologicheskie nahodki i raskopki v Kieve i v Kievskoy gubernii $\mathrm{v}$ techenii 1876 goda [Archaeological finds and excavations in Kiev and Kiev province in 1876.]. Chteniya $v$ istoricheskom obschestve Nestora-letopistsa-Readings in the Historical Society of Nestor the Chronicler, 1, 244 - 261 [in Russian].

11. Kulakovskiy Yu. A. (1891.) Arheologicheskie raskopki bliz Kerchi letom $1890 \mathrm{~g}$. [Archaeological excavations near Kerch in the summer of 1890.] Chteniya $v$ istoricheskom obschestve Nestora-letopistsa - Readings in the Historical Society of Nestor the Chronicle, 5, 20-25 [in Russian].

12. Antonovich V. B. (1880) 0 rezultatah arheologicheskoy ekspeditsii po severnomu sklonu Kavkaza, sovershennoy letom $1879 \mathrm{~g}$. [About the results of the archaeological 
expedition along the northern slope of the Caucasus, committed in the summer of 1879.]. Chteniya $v$ Istoricheskom obschestve Nestora-letopistsa-Readings in the Historical Society of Nestor the Chronicle, 2, 114-118. [in Russian].

Received 13.05.2018

Received in revised form 15.06.2018

Accepted 20.06.2018 